\title{
Autochthonous probiotic mixture improves biometrical parameters of larvae of Piaractus mesopotamicus (Caracidae, Characiforme, Teleostei)
}

\author{
Marcos Gabriel Guidoli ${ }^{1,2}$ (อ) Jorge Arnaldo Mendoza $^{1}$ Sofia Lizardo Falcón ${ }^{1}$ \\ Silvia Irene Boehringer ${ }^{2}$ Sebastián Sánchez ${ }^{1}$ María Elena Fátima Nader Macías ${ }^{3}$
}

${ }^{1}$ Instituto de Ictiología del Nordeste (INICNE), Facultad de Ciencias Veterinarias, Universidad Nacional del Nordeste (UNNE), 3400, Corrientes, Argentina. E-mail: marcosguidoli@hotmail.com. "Corresponding author.

${ }^{2}$ Cátedra de Microbiología, Facultad de Ciencias Veterinarias, Universidad Nacional del Nordeste (UNNE), Corrientes, Argentina.

${ }^{3}$ Centro de Referencia para Lactobacilos (CERELA-CONICET), Tucumán, Argentina.

\begin{abstract}
Probiotics are a novel alternative to antibiotics as growth factors. Previously, our group isolated, selected and tested in vivo, eight autochthonous strains. They showed no significant effects when administered individually. However, the best doses, stages and ways of administration were combined in a multi strain formula. The aim of this research was to evaluate the effect of this probiotic product on the growth and survival of Piaractus mesopotamicus larvae. The administration was implemented during egg incubation and endogenous feeding period (5), during larvae exogenous feeding period (10) and all along the experiment (15). A group without microorganisms was used as control. The probiotic generates significant increments of mean weight and not significant increases of survival and biomass in two of the three tested stages. These results demonstrate the effectiveness of an autochthonous probiotic formula for the culture of this native fish species. Key words: Lactic acid bacteria, Bacillus, Pacú, larviculture.
\end{abstract}

Mistura probiótica autótona melhora os parâmetros biométricos nas larvas de Piaractus mesopotamicus (Caracidae, Characiforme, Teleostei)

RESUMO: Os probióticos são uma alternativa inovadora aos antibióticos como fatores de crescimento. Anteriormente, nosso grupo isolou, selecionou e testou in vivo oito cepas autóctones. Estas não apresentaram efeitos significativos quando administrados individualmente. No entanto, as melhores doses, etapas e formas da administração foram combinadas para a formulação de um produto contendo multiples cepa. O objetivo deste trabalho foi avaliar o efeito deste produto probiótico no crescimento e sobrevivência de larvas de Piaractus mesopotamicus. A administração foi implementada durante a incubação de ovos e período de alimentação endógeno (5), durante o período de alimentação exógeno das larvas (10) e ao longo do experimento (15). Um grupo sem microrganismos foi utilizado como controle. O probiótico gera um incremento significativo de peso médio e não significativo de sobrevivência e biomassa em dois dos três estágios testados. Estes resultados demonstram a eficácia de uma fórmula probiótica autóctone para a cultura desta espécie de peixe nativa.

Palavras-chave: aquicultura, probióticos, crescimento, bactérias do ácido lático, Bacillus.

\section{INTRODUCTION}

Fishing capture is diminishing since 1996 (FAO 2016), while worldwide fish consumption is expected to increase until 2030 (WORLD BANK, 2013). The generated gap is fulfilled by increments in aquaculture (FAO 2009 and 2008). Piaractus mesopotamicus (Pacú) is a native fish species from Parana River and the most produced fish in Argentinean aquaculture. In the last years its production stagnated, probably due to deficits of animals for fattening, breeding and reproduction. Low mean weight and survival values could be due to a low knowledge of the staff, high stress conditions of animals and scarce technology applied during production process (MINISTERIO DE AGRICULTURA, GANADERÍA, PESCA Y ALIMENTOS DE LA NACIÓN ARGENTINA, 2015).

Antibiotics were used as growth factors to increment productivity. However, their use could produce residual drugs and affect consumers and expose not only the environment but also untargeted animals to these drugs (SMITH, 2008). Worldwide Organizations prohibited the use of antibiotics as growth promoters in animals for human consumption (EFSA, 2008), generating the need of novel strategies to increment productivity, while avoiding the use of chemotherapeutic and related drugs. Probiotics emerged as a putative solution. 
They are defined for aquaculture as "a live microbial adjunct which has a beneficial effect on the host by modifying the host associated or ambient microbial community, by supporting an improved use of feed or enhancing its nutritional value, by stimulating the host response or by improving the quality of its ambient environment" (VERSCHUERE et al., 2000). The composition of the probiotic product is a critical aspect. Commercial probiotics have shown relative ineffectiveness, probably for including nonautochthonous strains. Isolates from non-aquatic animals have low possibilities to survive and adhere in the intestinal environment of fish (RIDHA \& $\mathrm{AZAD}$, 2015). Another aspect to consider is that several authors confirm that the administration of more than one strain could generate higher benefits by the complementation of beneficial properties or synergic effect (DE et al., 2014).

Previously, our group isolated, selected and tested in vivo eight autochthonous strains: four Enterococcus faecium, three Bacillus subtilis and one Pediococcus acidilactici. The results of these tests allowed us to select the most efficient doses of each microorganism for the formulation of a multi strain probiotic product for future assays (GUIDOLI et al., 2015, 2016a and 2016b).

The aim of this research was to determine the viability of the selected bacteria in the aquaculture environment and live food suspension and to evaluate the effect of the multi strain probiotic product on the biometrical parameters of $P$. mesopotamicus eggs and larvae under intensive culture system.

\section{MATERIALS AND METHODS}

The following methods and techniques were planned in order to prove the hypothesis that the administration of a multi-strain probiotic, formulated with strains able to resist the environmental conditions and included in an adequate dose, improves the biometrical parameters of larvae of Piaractus mesopotamicus.

\section{Facilities, Animals and microorganisms}

The present study was carried out in the facilities of the Instituto de Ictiología del Nordeste (INICNE) and Cátedra de Microbiología from the Facultad de Ciencias Veterinarias of the Universidad Nacional del Nordeste in the province of Corrientes, Argentina.

The larvae were obtained by controlled reproduction of breeders maintained in the facilities of INICNE. Spawning was induced by injection of pituitary extract from Prochilodus lineatus. Sexual gametes were obtained by stripping, immediately mixed, suspended in fresh water, washed and resuspended to obtain the desired concentration (GÓMEZ et al., 2014).

Bacterial strains were isolated from Piaractus mesopotamicus, selected by their in-vitro expression of beneficial properties, genetically identified, registered in culture collections, tested in vivo individually and protected by patent aims (CONICET \& UNNE, 2013; GUIDOLI et al., 2015, 2016a and 2016b). Lactic acid bacteria (LAB) and Bacillus cells were grown at $37^{\circ} \mathrm{C}$ in LAPTg ( $1 \%$ yeast extract, $1.5 \%$ peptone, $1 \%$ tryptone, $1 \%$ glucose, $0.1 \%$ Tween $80 ; \mathrm{pH} 7.2$ ) and Nutrient Broth $\left(\right.$ Britania $\left.^{\odot}\right)$, respectively. Bacterial cells were obtained by centrifugation, and re-suspended in saline solution at the desired concentrations. The multi-strain suspension (MIX) contains the eight strains combined in previously determined concentrations (GUIDOLI et al., 2016a and 2016b) (Table 1).

Table 1 - Autochthonous putative probiotics and their doses in the MIX suspension.

\begin{tabular}{|c|c|c|}
\hline KJ740152 & E. faecium CRL 1937 & $6 \times 10^{7}$ \\
\hline KJ740153 & E. faecium CRL 1938 & $6 \times 10^{7}$ \\
\hline KJ740154 & P. acidilactici CRL1939 & $6 \times 10^{4}$ \\
\hline KJ740156 & E. faecium CRL 1941 & $6 \times 10^{4}$ \\
\hline KJ740155 & E. faecium CRL 1940 & $6 \times 10^{4}$ \\
\hline KJ754388 & B. subtilis A252 & $6 \times 10^{7}$ \\
\hline KJ740157 & B. subtilis A253 & $6 \times 10^{7}$ \\
\hline KJ740158 & B. subtilis A254 & $6 \times 10^{7}$ \\
\hline
\end{tabular}


Characterization of bacteria in the experimental units and the live food suspension

Aliquots of $10 \mathrm{~mL}$ sterile fishbowls' water were inoculated, individually, with $1 \times 10^{10}$ CFU $\mathrm{mL}^{-1}$ of each strain and maintained at room temperature for $4 \mathrm{~h}$. Viability was evaluated every hour by the technique of serial dilutions, subjected to subsequent inoculation in specific media and incubation at $37^{\circ} \mathrm{C}$ for $24 \mathrm{~h}$. The number of viable cells was expressed as the number of colony forming units (CFU) per $\mathrm{mL}$ of sample (CFU $\left.\mathrm{mL}^{-1}\right)$. The same procedure was applied to tubes containing $10 \mathrm{~mL}$ of a suspension containing 2,000 Artemia sp. $\mathrm{mL}^{-1}$ in order to evaluate the bacteria viability in the pellet and in the supernatant of the centrifuged suspensions. Both assays were performed by triplicate.

\section{Experimental design}

Experimental units consisted of $5-\mathrm{L}$ plastic fishbowls, with constant water exchange and 300 fecundated eggs. There were a control group and three different treatments: a 5-days period administration ranging from eggs fertilization to the beginning of exogenous feeding - treatment 5 -, a 10-days period ranging from the beginning of exogenous feeding to the end of the assay -treatment 10- and a 15-days period ranging from eggs fertilization to the end of the assay - treatment 15-. Bacteria were administered four times a day, directly into water the first 5 days and together with live food (Artemia sp.), after a 2-hours coincubation, from day 6 up to day 15 . At the end of the experiment animals were counted and weighed in order to obtain values of survival -expressed as percentage-, mean weight and total produced biomass. For microbial evaluations, three larvae of each replica were, individually, washed three times with sterile water and homogenized in $2 \mathrm{~mL}$ of sterile saline solution. The obtained suspension was plated into LAPTg agar for LAB and Nutrient agar, with or without previous heating at $80^{\circ} \mathrm{C}$ for 15 minutes, for Bacillus and general microorganisms, respectively. Results were expressed as CFU animal $^{-1}$. Finally, macro and microscopic evaluations were performed to assess the normal development and behavior of animals. Histological evaluations were implemented to detect adverse effects in the normal tissue structures.

Results were analyzed by means of a one-way analysis of variance (ANOVA), using a completely randomized design with one control, three treatments and three replications $(n=12)$.
Duncan's multiple range test was used as a post hoc test to compare differences between means. Statistical significance was settled at a probability value of $p<0.05$. The software used for data analysis was Statistica 6.0 for Microsoft Windows.

\section{Ethics and biosafety}

Approved by protocols 0019/14-201102204 and 14-2012-03865 by the Ethics and Biosafety Committee - Facultad de Ciencias Veterinarias Universidad Nacional del Nordeste, Argentina.

\section{RESULTS AND DISCUSSION}

The probiotic treatment proposed in this paper was formulated from previously obtained results of in vivo tests, based on the idea that multi strain autochthonous probiotic products could generate higher benefits by complementation of beneficial properties (DE et al., 2014). The experimental design was planned to fit with the normal procedures performed in any aquaculture production in order to facilitate the use of the potential probiotic product.

Artemia sp. not only has a proper size and great nutritional value but also is an adequate vehicle to deliver other substances such as nutrients, antimicrobials, vaccines and probiotics (AZIMIRAD et al., 2016; JAMALI et al., 2015). Thus, in the first stage of this investigation, it was proved that all strains remain viable in the water of the experimental units with no significant modifications in the number of viable cells after 4 hours. Same results were obtained in the pellet -Artemia naupliiand supernatant -water of the suspension- of the live feed suspension. Figure 1 shows that there are no significant differences $-p>0.05$ - between the affinity of each strain and the supernatant of the Artemia suspension. However, the adherence to the Artemia nauplii shows significant differences $-\mathrm{p}<0.05$-, with E. faecium CRL 1940, and B. subtilis A252, A253 and A254 presenting the highest values. These results indicated the survival of selected strains in the environment of fishes and their ability to adhere to the vehicle used to deliver the microorganisms.

The results of the in vivo tests show that all treatments induce higher average values of mean weight, survival and produced biomass than in the control group. However, only the values of mean weight presented significant differences $-p<0.05-$, with groups administered in stages 10 and 15 differentiating significantly from control and administered-in-stage-5 groups. These increments 


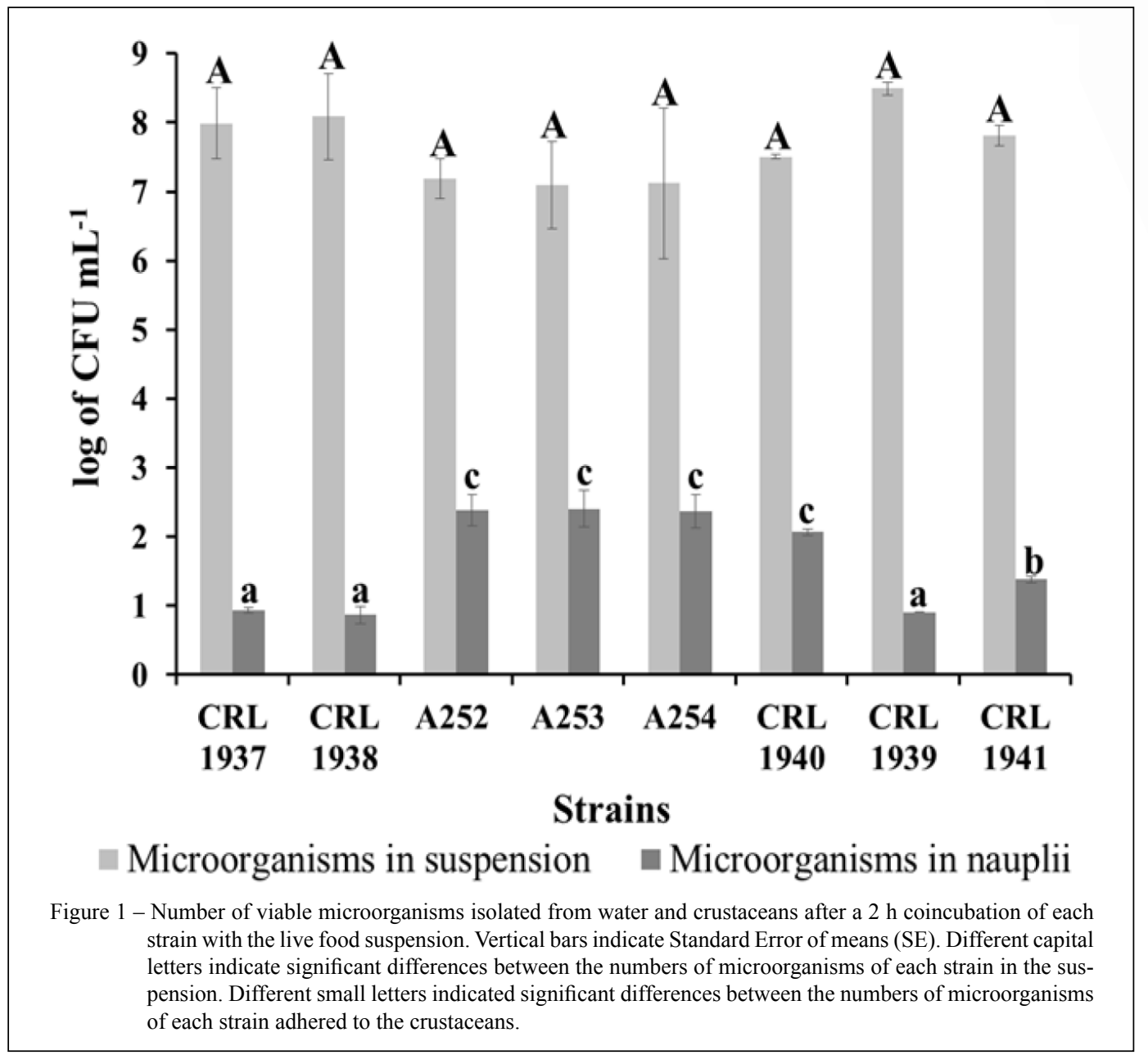

represent a $109.24 \%$ and $103.07 \%$ for stages 10 and 15 , respectively, referred to control group (Figure 2A). Survival increases, non-significantly, 2.00, 2.04 and 2.20 times compared with control values in treatments 5, 10 and 15, respectively (Figure 2B). Produced biomass in all treatments is also higher than in control group, with increments of $140.15 \%, 419.30 \%$ and $394.59 \%$ for stages 5, 10 and 15 respectively and without significance (Figure 2C). Literature in the area shows in vitro evaluations, modifications of immunological parameters and in vivo effects of potentially probiotic strains in animals challenged with pathogens. However, only a few articles describe probiotics able to increase biometrical parameters under non-challenge conditions (IBRAHEM, 2015). Our findings are consistent with those obtained by ABD EL-RHMAN et al. (2009), ZHOU et al. (2010), JATOBA et al. (2011) and ABUMOURAD et al.
(2014), who described significant increments in the mean weight of Nile tilapia after the administration of different probiotics, with no modifications in the survival rate.

Microbial evaluations showednosignificant differences $-\mathrm{p}>0.05$ - for total microorganisms between groups. Sporulated microorganisms are absent in the control group while its number increases significantly $-p<0.05-$ in treated groups. Conversely, the LAB count is significantly higher $-p<0.05$ - in the control than in treated groups (Figure 2D). In opposition to our findings, AZIMIRAD et al. (2016) reported significant increments in both, total microorganisms and LAB counts, accompanied by significant increments in weight gain when administering Pediococcus acidilactici and fructooligo saccharide to angelfish (Pterophyllum scalare). Increment in the number of sporulated microorganisms after its 


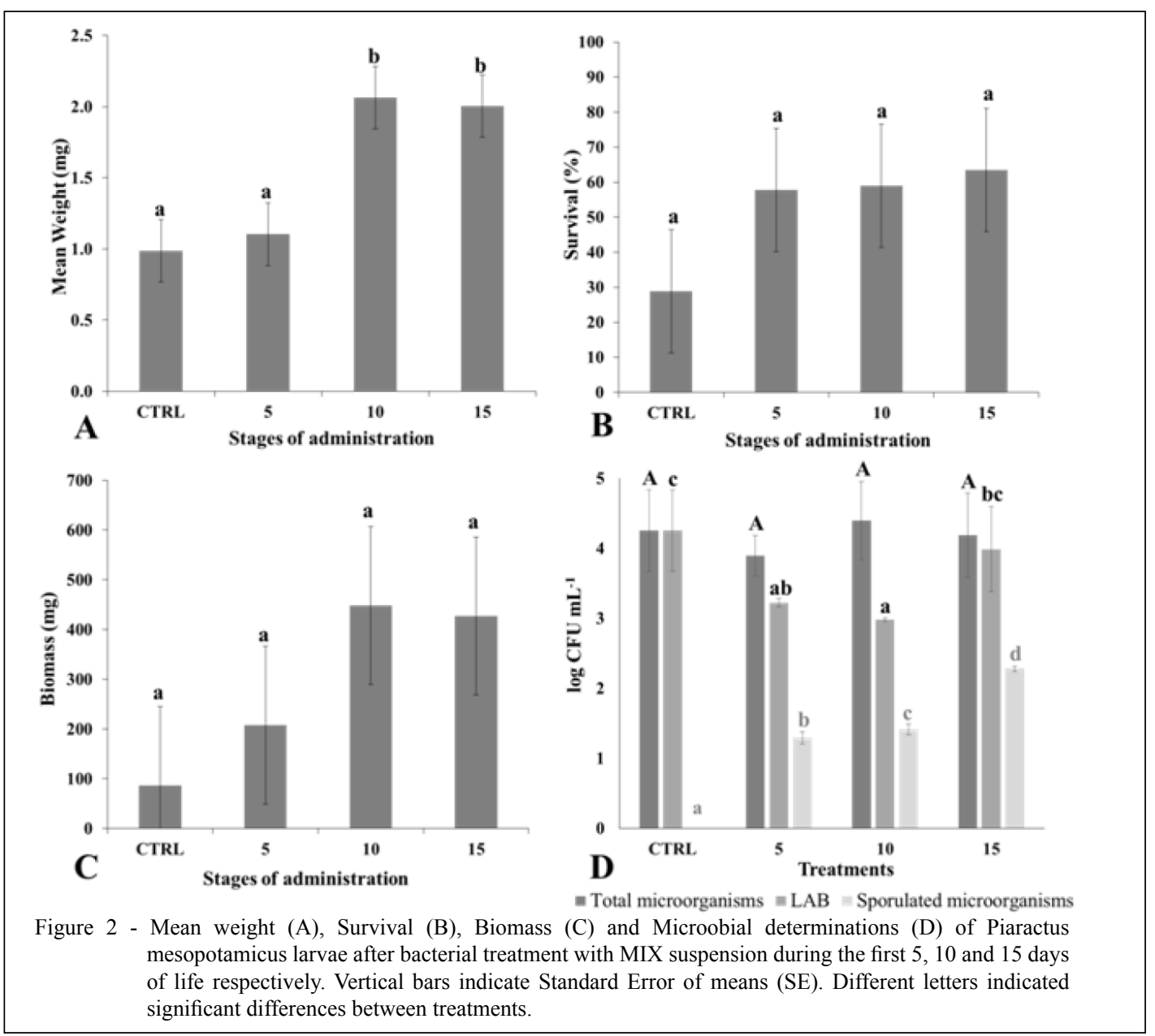

administration to aquatic animals was previously described by our group (GUIDOLI et al., 2016a). Also, JAMALI et al. (2015) and CHAI et al. (2016) demonstrated that shrimps administered with higher doses of Bacillus strains presented higher counts of sporulated microorganisms in their guts. In thisresearch the differences in the number of Bacillus cannot be related with the increment in the biometrical parameters. However, the studies in this research do not differentiate between genera, species or strains. Thus, the relative proportions of species or strains in each group of microorganisms could vary between treatments without being detected with the applied techniques. Further studies must be performed in order to monitor the proportions of the specific genera or species used in this research.

The development, behavior and histological structure of major organs, mainly those related to the digestive system (Figure 3), showed no differences between the control and treated groups.

There are no previous research stating the improvement of biometrical parameters of Piaractus mesopotamicus, the most produced native species in Argentinian aquaculture, by the administration of autochthonous probiotics. Results of the present work, allowed us to conclude that the use of the multi strain probiotic formula "MIX" would increment the survival, mean weight and produced biomass of Piaractus mesopotamicus under intensive production systems. These increments would not only raise the national production by supporting an increase of two important biological productivity factors such as growth and survival but also by encouraging other investors to participate in a more profitable entrepreneurship. 


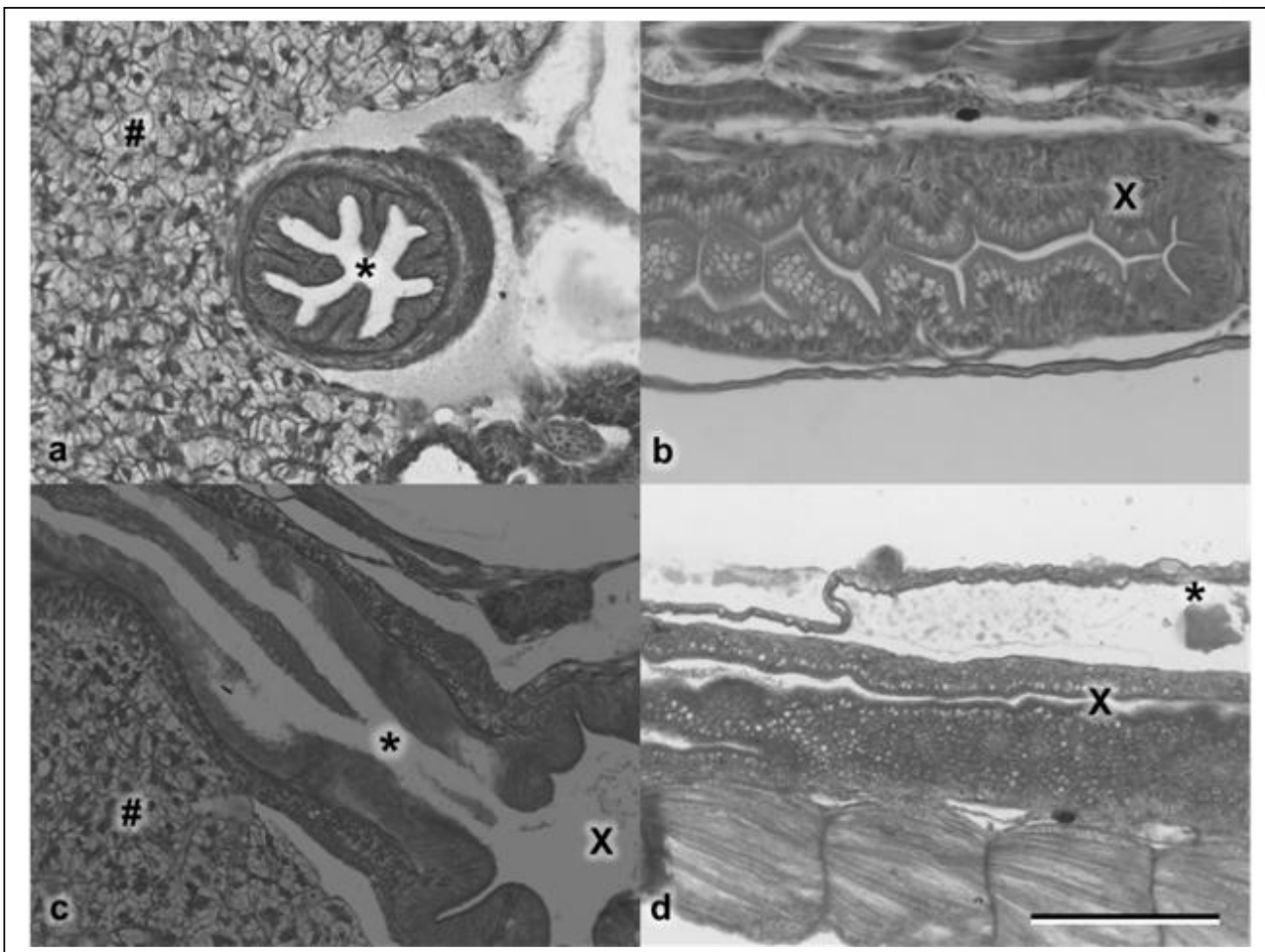

Figure 3 - Histology of stomach $(*)$, liver (\#) and intestine (X) of control (a) compared with animals treated with MIX suspension during the first 5 (b), 10 (c) and 15 (d) days of life respectively. Bars indicate $100 \mu \mathrm{m}$.

\section{DECLARATION OF CONFLICT OF INTEREST}

The authors declare no conflict of interest. The founding sponsors had no role in the design of the study; in the collection, analyses, or interpretation of data; in the writing of the manuscript, and in the decision to publish the results.

\section{REFERENCES}

ABD EL-RHMAN, A.M. et al. Micrococcus luteus and Pseudomonas species as probiotics for promoting the growth performance and health of Nile tilapia, Oreochromis niloticus. Fish \& Shellfish Immunology, v. 27, n. 2, p. 175-180, 2009. Accesed: Oct. 13, 2017. doi: 10.1016/j.fsi.2009.03.020.

ABUMOURAD, I.M.K. et al. Enterococcus faecium probiotic as a growth promoter and its impact on the expression of the host innate immune in cultured Oreochromis niloticus. Research Journal of Pharmaceutical, Biological and Chemical Sciences, v. 5, n. 2, p. 1747-1761, 2014. Available from: $<$ https://www.scopus.com/record/ display.uri?eid=2-s2.0-84896519789\&origin $=$ inward\&txGid=1a6c 9a75cd539768df2c102ec3a83373>. Accesed: Oct. 13, 2017.

AZIMIRAD, M. et al. The effects of feeding with synbiotic (Pediococcus acidilactici and fructooligosaccharide) enriched adult Artemia on skin mucus immune responses, stress resistance, intestinal microbiota and performance of angelfish (Pterophyllum scalare). Fish \& Shellfish Immunology, v. 54, p. 516-522, 2016. Accesed: Oct. 13, 2017. doi: 10.1016/j.fsi.2016.05.001.
CHAI, P.C. et al. Dietary supplementation of probiotic Bacillus PC465 isolated from the gut of Fenneropenaeus chinensis improves the health status and resistance of Litopenaeus vannamei against white spot syndrome virus. Fish \& Shellfish Immunology, v. 54, p. 602-611, 2016. Accesed: Oct. 13, 2017. doi: 10.1016/j. fsi.2016.05.011.

CONICET (Consejo Nacional de Investigaciones Científicas y Técnicas), UNNE (Universidad Nacional del Nordeste) (2013) Composición para mejorar la cría de peces de agua dulce y método de mejoramiento de la cría. Argentinian Patent 20130103820, 22 Oct. 2013.

DE, B.C. et al. Probiotics in fish and shellfish culture: immunomodulatory and ecophysiological responses. Fish Physiology \& Biochemistry, v. 40, n. 3, p. 921-971, 2014. Available from: $<$ https://link.springer.com/article/10.1007\%2Fs10695-013-9897-0>. Accesed: Oct. 13, 2017. doi: 10.1007/s10695-013-9897-0.

EFSA (European Food Safety Authority). Technical guidance: Update of the criteria used in the assessment of bacterial resistance to antibiotics of human or veterinary importance. EFSA, 2008. 15p. Boletim Técnico, 732.

FAO (Food and Agriculture Organization) Climate change for fisheries and aquaculture. Technical background document from the expert consultation. FAO, 2008. 18p. Boletim Técnico, 787.

FAO. The State of World Fisheries and Aquaculture 2008. FAO, 2009. 45p. Boletim Técnico, 250. 
FAO. The State of World Fisheries and Aquaculture 2016. Contributing to food security and nutrition for all. FAO, 2016. 204p. Boletim Técnico, 5555.

GÓMEZ, M.I. et al. Shrinkage of Prochilodus lineatus (Valenciennes, 1847) larvae preserved in either ethyl-alcohol or formalin in relation to their developmental stage and feeding condition. Journal of Applied Ichthyology, v. 30, p. 140-144, 2014. Available from: <https:// onlinelibrary.wiley.com/action/doSearch?AllField=Shrinkage + of $+\operatorname{Pr}$ ochilodus + lineatus $+\% 28$ Valenciennes $\% 2 \mathrm{C}+1847 \% 29+$ larvae+preser ved+in+either+ethyl-alcohol+or+formalin+in+relation+to+their+dev elopmental + stage + and + feeding + condition\&SeriesKey $=14390426>$. Accesed: Oct. 13, 2017. doi: 10.1111/jai.12308.

GUIDOLI, M.G. et al. Isolation and selection of potentially beneficial autochthonous bacteria for Piaractus mesopotamicus aquaculture activities. Journal of Bioprocessing Biotechniques, v.5, n. 254, 2015. Available from: ‘https://www.omicsonline.org/open-access/isolation-and-selection-ofpotentially-beneficial-autochthonous-bacteria-for-piaractus-mesopotamicusaquaculture-activities-2155-9821-1000254.php?aid=61083>. Accesed: Oct. 13, 2017. doi: 10.4172/2155-9821.1000254.

GUIDOLI, M.G. et al. Administration of three autochthonous Bacillus subtilis strains induce early appearance of gastric glands and vestiges of pylorus in Piaractus mesopotamicus larvae. Journal of Bioprocessing Biotechniques, v. 6, n. 271, 2016a. Available from: <https://tokdoc. tips/download-pdf-administration-of-three-autochthonous-bacillussubtilis-strains-induce-early-appearance-of-gastric-glands-andvestiges-of-pylorus-in-piaractus-mesopotamicus-larvae.html>. Accessed: Oct. 13, 2017. doi: 10.4172/2155-9821.1000271.

GUIDOLI, M.G. et al. In vivo evaluation of indigenous Enterococci strains on biometrical parameters of Piaractus mesopotamicus embryos and larvae. International Journal of Aquaculture, v.6, n. 2, $2016 \mathrm{~b}$. Available from: $<$ http://biopublisher.ca/index.php/ija/search/search?qu ery $=\mathrm{In}+\mathrm{vivo}+$ evaluation + of + indigenous + Enterococci + strains + on + bio metrical + parameters + of + Piaractus + mesopotamicus + embryos + and + lar vae\&authors $=\&$ title $=\&$ abstract $=$ \&alleyFullText $=\&$ suppFiles $=\&$ dateF romMonth $=\&$ dateFromDay $=\&$ dateFromYear $=\&$ dateToMonth $=\&$ date ToDay $=\&$ date $T o Y e a r=\&$ dateToHour $=23 \&$ dateToMinute $=59 \&$ dateToS econd $=59 \&$ discipline $=\&$ subject $=\&$ type $=\&$ coverage $=\&$ indexTerms $=>$. Accesed: Oct. 13, 2017. doi:10.5376/ija.2016.06.0002.

IBRAHEM, M.D. Evolution of probiotics in aquatic world: Potential effects, the current status in Egypt and recent prospectives. Journal of Advanced Research, v.6, n.6,p.765-791,2015.Availablefrom: $<$ https://
www.sciencedirect.com/science/article/pii/S2090123213001483>. Accesed: Oct. 13, 2017. doi:10.1016/j.jare.2013.12.004.

JAMALI, H. et al. Use of probiotic Bacillus spp. in Rotifer (Brachionus plicatilis) and Artemia (Artemia urmiana) Enrichment: Effects on Growth and Survival of Pacific White Shrimp, Litopenaeus vannamei, Larvae. Probiotics \& Antimicrobial Proteins, v. 7, n. 2, p. 118-125, 2015. Available from: <https://www.ncbi.nlm.nih.gov/pubmed/25721675>. Accessed: Oct. 13, 2017. doi: 10.1007/s12602-015-9189-3.

JATOBA, A. et al. Diet supplemented with probiotic for Nile tilapia in polyculture system with marine shrimp. Fish Physiology \& Biochemistry, v. 37, n. 4, p. 725-732, 2011. Available from: <https:// link.springer.com/article/10.1007/s10695-011-9472->. Accessed: Oct. 13, 2017. doi: 10.1007/s10695-011-9472-5.

MINISTERIO DE AGRICULTURA, GANADERÍA, PESCA Y ALIMENTOS DE LA NACIÓN ARGENTINA. DIRECCIÓN DE ACUICULTURA, 2015. 11p. Boletim Institucional, Agosto 2015.

RIDHA, M.T., AZAD, I.S. Effect of autochthonous and commercial probiotic bacteria on growth, persistence, immunity and disease resistance in juvenile and adult Nile tilapia Oreochromis niloticus. Aquaculture Research, v. 47, n. 9, p. 2757-2767, 2015. Available from: $\quad<$ https://onlinelibrary.wiley.com/action/doSearch?AllField=Ef fect + of + autochthonous + and + commercial + probiotic + bacteria + on $+g$ rowth $\% 2 \mathrm{C}+$ persistence $\% 2 \mathrm{C}+$ immunity + and + disease + resistance + in + juvenile + and + adult + Nile+tilapia + Oreochromis + niloticus\&SeriesK ey $=13652109>$. Accessed: Oct. 13, 2017. doi: 10.1111/are.12726.

SMITH, P. Antimicrobial resistance in aquaculture. Revue scientifique et technique, v. 27, n. 1, p. 243-264, 2008. Available from: <https:// www.ncbi.nlm.nih.gov/pubmed/18666490\#>. Accessed: Oct. 13, 2017.

VERSCHUERE, L. et al. Probiotic bacteria as biological control agents in aquaculture. Microbiology and molecular biology reviews, v. 64, n. 4, p. 655-671, 2000. Available from: <https://www.ncbi.nlm.nih.gov/ pmc/articles/PMC99008/pdf/mr000655.pdf $>$. Accessed: Oct. 13, 2017.

WORLD BANK. Fish to 2030: prospects for fisheries and aquaculture. World Bank, 2013. 102p. Boletim Técnico, 83177-GLB.

ZHOU, X. et al. Effect of treatment with probiotics as water additives on tilapia (Oreochromis niloticus) growth performance and immune response. Fish Physiology \& Biochemistry, v. 36, n. 3, p. 501-9, 2010. Accessed: Oct. 13, 2017. doi: 10.1007/s10695-009-9320-z. 